4

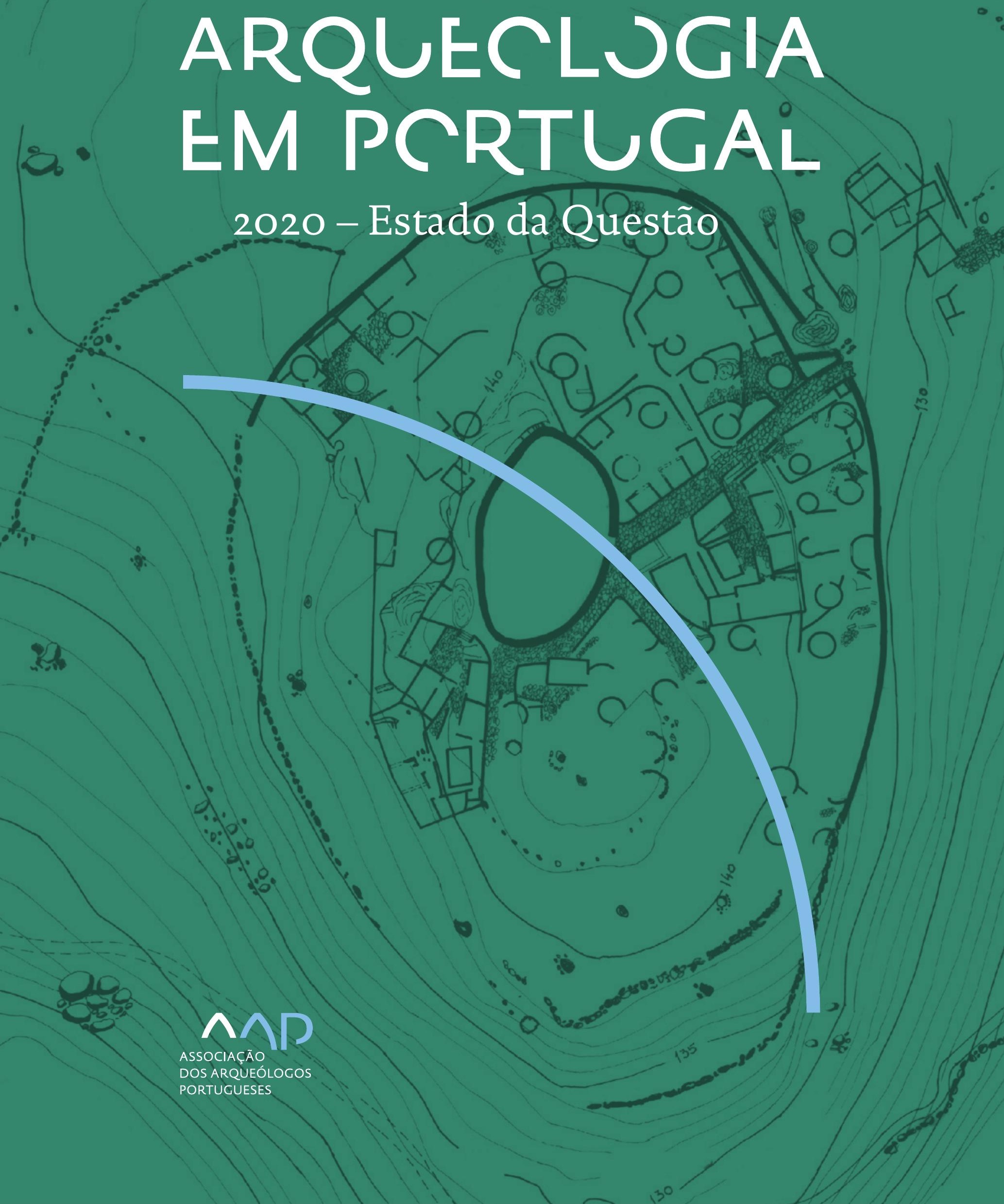


Coordenação editorial: José Morais Arnaud, César Neves e Andrea Martins Design gráfico: Flatland Design

AAP - ISBN: 978-972-9451-89-8

CITCEM - ISBN: 978-989-8970-25-1

Associação dos Arqueólogos Portugueses e CITCEM

Lisboa, 2020

O conteúdo dos artigos é da inteira responsabilidade dos autores. Sendo assim a Associação dos Arqueólogos Portugueses declina qualquer responsabilidade por eventuais equívocos ou questões de ordem ética e legal.

Desenho de capa:

Planta do castro de Monte Mozinho (Museu Municipal de Penafiel).

\section{$\hat{\wedge} \mathrm{P}$}

DOS ARQUEÓLOGOS PORTUGUESES

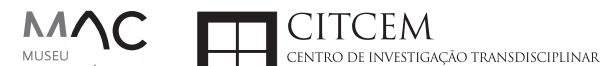
MUSEU
ARQUELLÓGICO
DO CARMO
U.PORTO

FLUP FACULDADE DE LETRAS
UNIVERSIDADE DO PORTO

Apoio

EC para a Ciência 


\section{Índice}

15 Prefácio

José Morais Arnaud

\section{Historiografia e Teoria}

17 Território, comunidade, memória e emoção: a contribuição da história da arqueologia (algumas primeiras e breves reflexões)

Ana Cristina Martins

25 Como descolonizar a arqueologia portuguesa?

Rui Gomes Coelho

41 Arqueologia e Modernidade: uma revisitação pessoal e breve de alguns aspetos da obra homónima de Julian Thomas de 2004

Vítor Oliveira Jorge

57 Dados para a História das Mulheres na Arqueologia portuguesa, dos finais do século XIX aos inícios do século XX: números, nomes e tabelas

Filipa Dimas / Mariana Diniz

73 Retractos da arqueologia portuguesa na imprensa: (in)visibilidades no feminino

Catarina Costeira / Elsa Luís

85 Arqueologia e Arqueólogos no Norte de Portugal Jacinta Bugalhão

101 Vieira Guimarães (1864-1939) e a arqueologia em Tomar: uma abordagem sobre o território e as gentes

João Amendoeira Peixoto / Ana Cristina Martins

115 Os memoráveis? A arqueologia algarvia na imprensa nacional e regional na presente centúria (2001-2019): características, visões do(s) passado(s) e a arqueologia

enquanto marca

Frederico Agosto / João Silva

129 A Evolução da Arqueologia Urbana e a Valorização Patrimonial no Barlavento Algarvio: Os casos de Portimão e Silves

Artur Mateus / Diogo Varandas / Rafael Boavida

\section{Gestão, Valorização e Salvaguarda do Património}

145 O Caderno Reivindicativo e as condições de trabalho em Arqueologia Miguel Rocha / Liliana Matias Carvalho / Regis Barbosa / Mauro Correia / Sara Simões / Jacinta Bugalhão / Sara Brito / Liliana Veríssimo Carvalho / Richard Peace / Pedro Peça / Cézer Santos

155 Os Estudos de Impacte Patrimonial como elemento para uma estratégia sustentável de minimização de impactes no âmbito de reconversões agrícolas Tiago do Pereiro

165 Salvaguarda de Património arqueológico em operações florestais: gestão e sensibilização Filipa Bragança / Gertrudes Zambujo / Sandra Lourenço / Belém Paiva / Carlos Banha / Frederico Tatá Regala / Helena Moura / Jacinta Bugalhão / João Marques / José Correia / Pedro Faria / Samuel Melro

179 Os valores do Património: uma investigação sobre os Sítios Pré-históricos de Arte Rupestre do Vale do Rio Côa e de Siega Verde José Paulo Francisco 
189 Conjugando recursos arqueológicos e naturais para potenciar as visitas ao Geoparque Litoral de Viana do Castelo (Noroeste de Portugal)

Hugo A. Sampaio / Ana M.S. Bettencourt / Susana Marinho / Ricardo Carvalhido

203 Áreas de Potencial Arqueológico na Região do Médio Tejo: Modelo Espacial Preditivo Rita Ferreira Anastácio / Ana Filipa Martins / Luiz Oosterbeek

223 Património Arqueológico e Gestão Territorial: O contributo da Arqueologia para a revisão do PDM de Avis

Ana Cristina Ribeiro

237 A coleção arqueológica do extinto Museu Municipal do Porto - Origens, Percursos e Estudos

Sónia Couto

251 Valpaços - uma nova carta arqueológica

Pedro Pereira / Maria de Fátima Casares Machado

263 Arqueologia na Cidade de Peniche

Adriano Constantino / Luís Rendeiro

273 Arqueologia Urbana: a cidade de Lagos como caso de Estudo Cátia Neto

285 Estratégias de promoção do património cultural subaquático nos Açores. O caso da ilha do Faial

José Luís Neto / José Bettencourt / Luís Borges / Pedro Parreira

297 Carta Arqueológica da Cidade Velha: Uma primeira abordagem

Jaylson Monteiro / Nireide Tavares / Sara da Veiga / Claudino Ramos / Edson Brito /

Carlos Carvalho / Francisco Moreira / Adalberto Tavares

311 Antropologia Virtual: novas metodologias para a análise morfológica e funcional Ricardo Miguel Godinho / Célia Gonçalves

\section{Didáctica da Arqueologia}

327 Como os projetos de Arqueologia podem contribuir para uma comunidade culturalmente mais consciente Alexandra Figueiredo / Claúdio Monteiro / Adolfo Silveira / Ricardo Lopes

337 Educação Patrimonial - Um cidadão esclarecido é um cidadão ativo! Ana Paula Almeida

351 A aproximação da Arqueologia à sala de aula: um caso de estudo no $3^{\circ}$ ciclo do Ensino Básico Luís Serrão Gil

363 Arqueologia 3.o - Pensar e comunicar a Arqueologia para um futuro sustentável Mónica Rolo

377 “Conversa de Arqueólogos" - Divulgar a Arqueologia em tempos de Pandemia Diogo Teixeira Dias

389 Escola Profissional de Arqueologia: desafios e oportunidades Susana Nunes / Dulcineia Pinto / Júlia Silva / Ana Mascarenhas

399 Os Museus de Arqueologia e os Jovens: a oferta educativa para o público adolescente Beatriz Correia Barata / Leonor Medeiros

411 O museu universitário como mediador entre a ciência e a sociedade: o exemplo da secção de arqueologia no Museu de História Natural e da Ciência da Universidade do Porto (MHNC-UP)

Rita Gaspar 
421 Museu de Lanifícios: Real Fábrica de Panos. Atividades no âmbito da Arqueologia Beatriz Correia Barata / Rita Salvado

427 Arqueologia Pública e o caso da localidade da Mata (Torres Novas) Cláudia Manso / Ana Rita Ferreira / Cristiana Ferreira / Vanessa Cardoso Antunes

431 Do sítio arqueológico ao museu: um percurso (também) didático Lídia Fernandes

447 Estão todos convidados para a Festa! E para dançar também... O projecto do Serviço Educativo do Museu Arqueológico do Carmo na $5^{\underline{a}}$ Edição da Festa da Arqueologia Rita Pires dos Santos

459 O “Clã de Carenque”, um projeto didático de arqueologia Eduardo Gonzalez Rocha

469 Mediação cultural: peixe que puxa carroça nas Ruínas Romanas de Troia Inês Vaz Pinto / Ana Patrícia Magalhães / Patrícia Brum / Filipa Santos

481 Didática Arqueológica, experiências do Projeto Mértola Vila Museu Maria de Fátima Palma / Clara Rodrigues / Susana Gómez / Lígia Rafael

\section{Arte Rupestre}

497 Os inventários de arte rupestre em Portugal Mila Simões de Abreu

513 O projeto FIRST-ART - conservação, documentação e gestão das primeiras manifestações de arte rupestre no Sudoeste da Península Ibérica: as grutas do Escoural e Maltravieso Sara Garcês / Hipólito Collado / José Julio García Arranz / Luiz Oosterbeek / António Carlos Silva / Pierluigi Rosina / Hugo Gomes / Anabela Borralheiro Pereira / George Nash / Esmeralda Gomes / Nelson Almeida / Carlos Carpetudo

523 Trabalhos de documentação de arte paleolítica realizados no âmbito do projeto PalæoCôa André Tomás Santos / António Fernando Barbosa / Luís Luís / Marcelo Silvestre / Thierry Aubry

537 Imagens fantasmagóricas, silhuetas elusivas: as figuras humanas na arte do Paleolítico Superior da região do Côa Mário Reis

$55^{1}$ Os motivos zoomórficos representados nas placas de tear de Vila Nova de São Pedro (Azambuja, Portugal) Andrea Martins / César Neves / José M. Arnaud / Mariana Diniz

571 Arte Rupestre do Monte de Góios (Lanhelas, Caminha). Síntese dos resultados dos trabalhos efectuados em 2007-2009 Mário Varela Gomes

599 Gravuras rupestres de barquiformes no Monte de S. Romão, Guimarães, Noroeste de Portugal Daniela Cardoso

613 Círculos segmentados gravados na Bacia do Rio Lima (Noroeste de Portugal): contributos para o seu estudo Diogo Marinho / Ana M.S. Bettencourt / Hugo Aluai Sampaio

631 Equídeos gravados no curso inferior do Rio Mouro, Monção (NW Portugal). Análise preliminar Coutinho, L.M. / Bettencourt, A.M.S / Sampaio, Hugo A.S

645 Paletas na Arte Rupestre do Noroeste de Portugal. Inventário preliminar Bruna Sousa Afonso / Ana M. S. Bettencourt / Hugo A. Sampaio 


\section{Pré-História}

661 O projeto Miño/Minho: balanço de quatro anos de trabalhos arqueológicos Sérgio Monteiro-Rodrigues / João Pedro Cunha-Ribeiro / Eduardo Méndez-Quintas / Carlos Ferreira / Pedro Xavier / José Meireles / Alberto Gomes / Manuel Santonja / Alfredo Pérez-González

677 A ocupação paleolítica da margem esquerda do Baixo Minho: a indústria lítica do sítio de Pedreiras 2 (Monção, Portugal) e a sua integração no contexto regional Carlos Ferreira / João Pedro Cunha-Ribeiro / Sérgio Monteiro-Rodrigues / Eduardo Méndez-Quintas / Pedro Xavier / José Meireles / Alberto Gomes / Manuel Santonja / Alfredo Pérez-González

693 O sítio acheulense do Plistocénico médio da Gruta da Aroeira Joan Daura / Montserrat Sanz / Filipa Rodrigues / Pedro Souto / João Zilhão

703 As sociedades neandertais no Barlavento algarvio: modelos preditivos com recurso aos SIG

Daniela Maio

715 A utilização de quartzo durante o Paleolítico Superior no território dos vales dos rios Vouga e Côa

Cristina Gameiro / Thierry Aubry / Bárbara Costa / Sérgio Gomes / Luís Luís / Carmen Manzano / André Tomás Santos

733 Uma perspetiva diacrónica da ocupação do concheiro do Cabeço da Amoreira (Muge, Portugal) a partir da tecnologia lítica Joana Belmiro / João Cascalheira / Célia Gonçalves

745 Novos dados sobre a Pré-história Antiga no concelho de Palmela. A intervenção arqueológica no sítio do Poceirão I

Michelle Teixeira Santos

757 Problemas em torno de Datas Absolutas Pré-Históricas no Norte do Alentejo Jorge de Oliveira

771 Povoamento pré-histórico nas áreas montanhosas do NO de Portugal: o Abrigo 1 de Vale de Cerdeira Pedro Xavier / José Meireles / Carlos Alves

783 Apreciação do povoamento do Neolítico Inicial na Baixa Bacia do Douro. A Lavra I (Serra da Aboboreira) como caso de estudo Maria de Jesus Sanches

797 O Processo de Neolitização na Plataforma do Mondego: os dados do Sector C do Outeiro dos Castelos de Beijós (Carregal do Sal)

João Carlos de Senna-Martinez / José Manuel Quintã Ventura / Andreia Carvalho / Cíntia Maurício

823 Novos trabalhos na Lapa da Bugalheira (Almonda, Torres Novas) Filipa Rodrigues / Pedro Souto / Artur Ferreira / Alexandre Varanda / Luís Gomes / Helena Gomes / João Zilhão

837 A pedra polida e afeiçoada do sítio do Neolítico médio da Moita do Ourives (Benavente, Portugal)

César Neves

857 Casal do Outeiro (Encarnação, Mafra): novos contributos para o conhecimento do povoamento do Neolítico final na Península de Lisboa.

Cátia Delicado / Carlos Maneira e Costa / Marta Miranda / Ana Catarina Sousa

873 Stresse infantil, morbilidade e mortalidade no sítio arqueológico do Neolítico Final/ Calcolítico ( $4^{\circ}$ e $3^{\circ}$ milénio a.C.) do Monte do Carrascal 2 (Ferreira do Alentejo, Beja) Liliana Matias de Carvalho / Sofia N. Wasterlain 
885 Come together: O Conjunto Megalítico das Motas (Monção, Viana do Castelo) e as expressões Campaniformes do Alto Minho Ana Catarina Basílio / Rui Ramos

899 Trabalhos arqueológicos no sítio Calcolítico da Pedreira do Poio Carla Magalhães / João Muralha / Mário Reis / António Batarda Fernandes

913 O sítio arqueológico de Castanheiro do Vento. Da arquitectura do sítio à arquitectura de um território João Muralha Cardoso

925 Estudo zooarqueológico das faunas do Calcolítico final de Vila Nova de São Pedro (Azambuja, Portugal): Campanhas de 2017 e 2018 Cleia Detry / Ana Catarina Francisco / Mariana Diniz / Andrea Martins / César Neves / José Morais Arnaud

943 As faunas depositadas no Museu Arqueológico do Carmo provenientes de Vila Nova de São Pedro (Azambuja): as campanhas de 1937 a 1967 Ana Catarina Francisco / Cleia Detry / César Neves / Andrea Martins / Mariana Diniz / José Morais Arnaud

959 Análise funcional de material lítico em sílex do castro de Vila Nova de S. Pedro (Azambuja, Portugal): uma primeira abordagem Rafael Lima

971 O recinto da Folha do Ouro 1 (Serpa) no contexto dos recintos de fossos calcolíticos alentejanos

António Carlos Valera / Tiago do Pereiro / Pedro Valério / António M. Monge Soares

\section{Proto-História}

987 Produção de sal marinho na Idade do Bronze do noroeste Português. Alguns dados para uma reflexão

Ana M. S. Bettencourt / Sara Luz / Nuno Oliveira / Pedro P. Simões / Maria Isabel C. Alves / Emílio Abad-Vidal

1001 A estátua-menir do Pedrão ou de São Bartolomeu do Mar (Esposende, noroeste de Portugal) no contexto arqueológico da fachada costeira de entre os rios Neiva e Cávado Ana M. S. Bettencourt / Manuel Santos-Estévez / Pedro Pimenta Simões / Luís Gonçalves

1015 O Castro do Muro (Vandoma/Baltar, Paredes) - notas para uma biografia de ocupação da Idade do Bronze à Idade Média

Maria Antónia D. Silva / Ana M. S. Bettencourt / António Manuel S. P. Silva / Natália Félix

1031 Do Bronze Final à Idade Média - continuidades e hiatos na ocupação de Povoados em Oliveira de Azeméis João Tiago Tavares / Adriaan de Man

1041 As faunas do final da Idade do Bronze no Sul de Portugal: leituras desde o Outeiro do Circo (Beja)

Nelson J. Almeida / Íris Dias / Cleia Detry / Eduardo Porfírio / Miguel Serra

1055 A Espada do Monte das Oliveiras (Serpa) - uma arma do Bronze Pleno do Sudoeste Rui M. G. Monge Soares / Pedro Valério / Mariana Nabais / António M. Monge Soares

1065 São Julião da Branca (Albergaria-a-Velha) - Investigação e valorização de um povoado do Bronze Final

António Manuel S. P. Silva / Paulo A. P. Lemos / Sara Almeida e Silva / Edite Martins de Sá

1083 Do castro de S. João ao Mosteiro de Santa Clara: notícia de uma intervenção arqueológica, em Vila do Conde Rui Pinheiro 
1095 O castro de Ovil (Espinho), um quarto de século de investigação - resultados e questões em aberto

Jorge Fernando Salvador / António Manuel S. P. Silva

1111 O Castro de Salreu (Estarreja), um povoado proto-histórico no litoral do Entre Douro e Vouga

Sara Almeida e Silva / António Manuel S. P. Silva / Paulo A. P. Lemos / Edite Martins de Sá

1127 Castro de Nossa Senhora das Necessidades (Sernancelhe): uma primeira análise artefactual Telma Susana O. Ribeiro

${ }_{1141}$ A cividade de Bagunte. O estado atual da investigação Pedro Brochado de Almeida

1153 Zoomorfos na cerâmica da Idade do Ferro no NW Peninsular: inventário, cronologias e significado Nuno Oliveira / Cristina Seoane

1163 Vasos gregos em Portugal: diferentes maneiras de contar a história do intercâmbio cultural na Idade do Ferro

Daniela Ferreira

1175 Os exotica da necrópole da Idade do Ferro do Olival do Senhor dos Mártires (Alcácer do Sal) no seu contexto regional

Francisco B. Gomes

\section{Antiguidade Clássica e Tardia}

1191 O uso de madeira como combustível no sítio da Quinta de Crestelos (Baixo Sabor): da Idade do Ferro à Romanização Filipe Vaz / João Tereso / Sérgio Simões Pereira / José Sastre / Javier Larrazabal Galarza / Susana Cosme / José António Pereira / Israel Espi

1207 Cultivos de Época Romana no Baixo Sabor: continuidade em tempos de mudança? João Pedro Tereso / Sérgio Simões Pereira / Filipe Santos / Luís Seabra / Filipe Vaz

1221 A casa romana na Hispânia: aplicação dos modelos itálicos nas províncias ibéricas Fernanda Magalhães / Diego Machado / Manuela Martins

1235 As pinturas murais romanas da Rua General Sousa Machado, n. ${ }^{5}$ 1, Chaves José Carvalho

1243 Trás do Castelo (Vale de Mir, Pegarinhos, Alijó) - Uma exploração agrícola romana do Douro

Tony Silvino / Pedro Pereira

1255 A sequência de ocupação no quadrante sudeste de Bracara Augusta: as transformações de uma unidade doméstica Lara Fernandes / Manuela Martins

1263 Os Mosaicos com decoração geométrica e geométrico-vegetalista dos sítios arqueológicos da área do Conuentus Bracaraugustanus. Novas abordagens quanto à conservação, restauro, decoração e datação Maria de Fátima Abraços / Licínia Wrench

1277 “Casa Romana” do Castro de São Domingos (Cristelos, Lousada): Escavação, Estudo e Musealização Paulo André de P. Lemos

1291 A arqueobotânica no Castro de Guifões (Matosinhos, Noroeste de Portugal): O primeiro estudo carpológico

Luís Seabra / Andreia Arezes / Catarina Magalhães / José Varela / João Pedro Tereso 
1305 Um Horreum Augustano na Foz do Douro (Monte do Castelo de Gaia, Vila Nova de Gaia) Rui Ramos

1311 Ponderais romanos na Lusitânia: padrões, formas, materiais e contextos de utilização Diego Barrios Rodríguez

1323 Um almofariz centro-itálico na foz do Mondego

Marco Penajoia

1335 Estruturas romanas de Carnide - Lisboa Luísa Batalha / Mário Monteiro / Guilherme Cardoso

1347 O contexto funerário do sector da "necrópole NO" da Rua das Portas de S. Antão (Lisboa): o espaço, os artefactos, os indivíduos e a sua interconectividade na interpretação do passado Sílvia Loja, José Carlos Quaresma, Nelson Cabaço, Marina Lourenço, Sílvia Casimiro, Rodrigo Banha da Silva, Francisca Alves-Cardoso

${ }_{1361}$ Povoamento em época Romana na Amadora - resultados de um projeto pluridisciplinar Gisela Encarnação / Vanessa Dias

1371 A Arquitectura Residencial em Mirobriga (Santiago do Cacém): contributo a partir de um estudo de caso Filipe Sousa / Catarina Felício

${ }_{1385}$ O fim do ciclo. Saneamento e gestão de resíduos nos edifícios termais de Mirobriga (Santiago do Cacém)

Catarina Felício / Filipe Sousa

1399 Balsa, Topografia e Urbanismo de uma Cidade Portuária Vítor Silva Dias / João Pedro Bernardes / Celso Candeias / Cristina Tété Garcia

1413 No Largo das Mouras Velhas em Faro (2017): novas evidências da necrópole norte de Ossonoba e da sua ocupação medieval Ricardo Costeira da Silva / Paulo Botelho / Fernando Santos / Liliana Nunes

1429 Instrumentos de pesca recuperados numa fábrica de salga em Ossonoba (Faro) Inês Rasteiro / Ricardo Costeira da Silva / Paulo Botelho

1439 A Necrópole Romana do Eirô, Duas Igrejas (Penafiel): intervenção arqueológica de 2016 Laura Sousa / Teresa Soeiro

1457 Ritual, descarte ou afetividade? A presença de Canis lupus familiaris na Necrópole Noroeste de Olisipo (Lisboa)

Beatriz Calapez Santos / Sofia Simões Pereira / Rodrigo Banha da Silva / Sílvia Casimiro / Cleia Detry / Francisca Alves Cardoso

1467 Dinâmicas económicas em Bracara na Antiguidade Tardia Diego Machado / Manuela Martins / Fernanda Magalhães / Natália Botica

1479 Cerâmicas e Vidros da Antiguidade Tardia do Edifício sob a Igreja do Bom Jesus (Vila Nova de Gaia) Joaquim Filipe Ramos

1493 Novos contributos para a topografia histórica de Mértola no período romano e na Antiguidade Tardia Virgílio Lopes

\section{8. Época Medieval}

1511 Cerâmicas islâmicas no Garb setentrional "português": algumas evidências e incógnitas Constança dos Santos / Helena Catarino / Susana Gómez / Maria José Gonçalves / Isabel Inácio / Gonçalo Lopes / Jacinta Bugalhão / Sandra Cavaco / Jaquelina Covaneiro / Isabel Cristina Fernandes / Ana Sofia Gomes 
1525 Contributo para o conhecimento da cosmética islâmica, em Silves, durante a Idade Média Rosa Varela Gomes

1537 Yábura e o seu território - uma análise histórico-arqueológica de Évora entre os séculos VIII-XII José Rui Santos

1547 A encosta sul do Castelo de Palmela - resultados preliminares da escavação arqueológica Luís Filipe Pereira / Michelle Teixeira Santos

1559 A igreja de São Lourenço (Mouraria, Lisboa): um conjunto de silos e de cerâmica medieval islâmica

Andreia Filipa Moreira Rodrigues

1571 O registo material de movimentações populacionais no Médio Tejo, durante os séculos XII-XIII. Dois casos de "sunken featured buildings", nos concelhos de Cartaxo e Torres Novas Marco Liberato / Helena Santos / Nuno Santos

1585 O nordeste transmontano nos alvores da Idade média. Notas para reflexão Ana Maria da Costa Oliveira

1601 Sepulturas escavadas na rocha do Norte de Portugal e do Vale do Douro: primeiros resultados do Projecto SER-NPVD

Mário Jorge Barroca / César Guedes / Andreia Arezes / Ana Maria Oliveira

1619 "Portucalem Castrum Novum" entre o Mediterrâneo e o Atlântico: o estudo dos materiais cerâmicos alto-medievais do arqueossítio da rua de D. Hugo, nํ. 5 (Porto) João Luís Veloso

1627 A Alta Idade Média na fronteira de Lafões: notas preliminares sobre a Arqueologia no Concelho de Vouzela

Manuel Luís Real / Catarina Tente

1641 Um conjunto cerâmico medieval fora de portas: um breve testemunho aveirense Susana Temudo

${ }_{1651}$ Os Lóios do Porto: uma perspetiva integrada no panorama funerário da Baixa Idade Média à Época Moderna em meios urbanos em Portugal

Ana Lema Seabra

1659 O Caminho Português Interior de Santiago como eixo viário na Idade Média Pedro Azevedo

1665 Morfologia Urbana: Um exercício em torno do Castelo de Ourém André Donas-Botto / Jaqueline Pereira

1677 Intervenção arqueológica na Rua Marquês de Pombal/Largo do Espírito Santo (Bucelas, Loures)

Florbela Estêvão / Nathalie Antunes-Ferreira / Dário Ramos Neves / Inês Lisboa

1691 O Cemitério Medieval do Poço do Borratém e a espacialidade funerária na cidade de Lisboa Inês Belém / Vanessa Filipe / Vasco Noronha Vieira / Sónia Ferro / Rodrigo Banha da Silva

1705 Um Espaço Funerário Conventual do séc. XV em Lisboa: o caso do Convento de São Domingos da Cidade Sérgio Pedroso / Sílvia Casimiro / Rodrigo Banha da Silva / Francisca Alves Cardoso

\section{9. Época Moderna e Contemporânea}

1721 Arqueologia Moderna em Portugal: algumas reflexões críticas em torno da quantificação de conjuntos cerâmicos e suas inferências históricas e antropológicas Rodrigo Banha da Silva / André Bargão / Sara da Cruz Ferreira

1733 Faianças de dois contextos entre os finais do século XVI e XVIII do Palácio dos Condes de Penafiel, Lisboa

Martim Lopes / Tomás Mesquita 
1747 Um perfil de consumo do século XVIII na foz do Tejo: O caso do Mercado da Ribeira, Lisboa Sara da Cruz Ferreira / Rodrigo Banha da Silva / André Bargão

1761 Os Cachimbos dos Séculos XVII e XVIII do Palácio Mesquitela e Convento dos Inglesinhos (Lisboa)

Inês Simão / Marina Pinto / João Pimenta / Sara da Cruz Ferreira / André Bargão / Rodrigo Banha da Silva

1775 "Tomar os fumos da erua que chamão em Portugal erua sancta». Estudo de Cachimbos provenientes da Rua do Terreiro do Trigo, Lisboa

Miguel Martins de Sousa / José Pedro Henriques / Vanessa Galiza Filipe

1787 Cachimbos de Barro Caulínitico da Sé da Cidade Velha (República de Cabo Verde)

Rodrigo Banha da Silva / João Pimenta / Clementino Amaro

1801 Algumas considerações sobre espólio não cerâmico recuperado no Largo de Jesus (Lisboa) Carlos Boavida

1815 Adereços de vidro, dos séculos XVI-XVIII, procedentes do antigo Convento de Santana de Lisboa (anéis, braceletes e contas)

Joana Gonçalves / Rosa Varela Gomes / Mário Varela Gomes

1837 Da ostentação, luxo e poder à simplicidade do uso quotidiano: arqueologia e simbologia de joias e adornos da Idade Moderna Portuguesa Jéssica Iglésias

1849 Os amuletos em Portugal - dos objetos às superstições: o coral vermelho Alexandra Vieira

1865 Cerâmicas de Vila Franca de Xira nos séculos XV e XVI Eva Pires

1879 «Não passa por teu o que me pertence». Marcas de individualização associadas a faianças do Convento de Nossa Senhora de Aracoeli, Alcácer do Sal Catarina Parreira / Íris Fragoso / Miguel Martins de Sousa

1891 Cerâmica de Leiria: alguns focos de produção

Jaqueline Pereira / André Donas-Botto

1901 Os Fornos na Rua da Biquinha, em Óbidos Hugo Silva / Filipe Oliveira

1909 A casa de Pêro Fernandes, contador dos contos de D. Manuel I: o sítio arqueológico da Silha do Alferes, Seixal (século XVI) Mariana Nunes Ferreira

1921 O Alto da Vigia (Sintra) e a vigilância e defesa da costa Alexandre Gonçalves / Sandra Santos

1937 O contexto da torre sineira da Igreja de Santa Maria de Loures Paulo Calaveira / Martim Lopes

1949 A Necrópole do Hospital Militar do Castelo de São Jorge e as práticas funerárias na Lisboa de Época Moderna Susana Henriques / Liliana Matias de Carvalho / Ana Amarante / Sofia N. Wasterlain

1963 SAND - Sarilhos Grandes Entre dois Mundos: o adro da Igreja e a Paleobiologia dos ossos humanos recuperados

Paula Alves Pereira / Roger Lee Jesus / Bruno M. Magalhães

1975 Expansão urbana da vila de Cascais no século XVII e XVIII: a intervenção arqueológica na Rua da Vitória no 15 a 17

Tiago Pereira / Vanessa Filipe

1987 Novos dados para o conhecimento do Urbanismo de Faro em época Moderna Ana Rosa 
1995 Um exemplo de Arqueologia Urbana em Alcoutim: o Antigo Edifício dos CTT Marco Fernandes / Marta Dias / Alexandra Gradim / Virgílio Lopes / Susana Gómez Martínez

2007 Palácio dos Ferrazes (Rua das Flores/Rua da Vitória, Porto): a cocheira de Domingos Oliveira Maia

Francisco Raimundo

2021 As muitas vidas de um edifício urbano: História, Arqueologia e Antropologia no antigo Recreatório Paroquial de Penafiel Helena Bernardo / Jorge Sampaio / Marta Borges

2035 O convento de Nossa Senhora da Esperança de Ponta Delgada: o contributo da arqueologia para o conhecimento de um monumento identitário João Gonçalves Araújo / N’Zinga Oliveira

2047 Arqueologia na ilha do Corvo... em busca da capela de Nossa Senhora do Rosário Tânia Manuel Casimiro / José Luís Neto / Luís Borges / Pedro Parreira

2059 Perdidos à vista da Costa. Trabalhos arqueológicos subaquáticos na Barra do Tejo Jorge Freire / José Bettencourt / Augusto Salgado

2071 Arqueologia marítima em Cabo Verde: enquadramento e primeiros resultados do projecto CONCHA

José Bettencourt / Adilson Dias / Carlos Lima / Christelle Chouzenoux / Cristóvão Fonseca / Dúnia Pereira / Gonçalo Lopes / Inês Coelho / Jaylson Monteiro / José Lima / Maria Eugénia Alves / Patrícia Carvalho / Tiago Silva

2085 Trabalhos arqueológicos na Cidade Velha (Ribeira Grande de Santiago, Cabo Verde): reflexões sobre um projecto de investigação e divulgação patrimonial André Teixeira / Jaylson Monteiro / Mariana Mateus / Nireide Tavares / Cristovão Fonseca / Gonçalo C. Lopes / Joana Bento Torres / Dúnia Pereira / André Bargão / Aurélie Mayer / Bruno Zélie / Carlos Lima / Christelle Chouzenoux / Inês Henriques / Inês Pinto Coelho / José Lima / Patrícia Carvalho / Tiago Silva

2103 A antiga fortificação de Quelba / Khor Kalba (E.A.U.). Resultados de quatro campanhas de escavações, problemáticas e perspectivas futuras Rui Carita / Rosa Varela Gomes / Mário Varela Gomes / Kamyar Kamyad

2123 Colónias para homens novos: arqueologia da colonização agrária fascista no noroeste ibérico Xurxo Ayán Vila / José Mạ . Señorán Martín 


\title{
MORFOLOGIA URBANA: UM EXERCÍCIO EM TORNO DO CASTELO DE OURÉM
}

\author{
André Donas-Botto ${ }^{1}$, Jaqueline Pereira ${ }^{2}$
}

\begin{abstract}
RESUMO
O estudo da fotografia aérea através da fotointerpretação e da fotointerpretação da morfologia urbana não é novidade na Arqueologia, ainda que cada vez mais se recorra a ela para tirar conclusões do foro arqueológico. Para além da identificação de possíveis sítios arqueológicos, a fotografia aérea é também um recurso para a leitura de morfologias urbanas. Aliás, é bastante útil na percepção da evolução do traçado da malha urbana.

Ao observarmos uma paisagem - urbana ou não - devemos sempre ter em atenção o seu dinamismo. Assim, através da detecção de transmissões Isotópicas, Isoaxiais e Isoclinas, propomo-nos desenvolver uma proposta de evolução morfológica do Núcleo Medieval de Ourém ao longo dos tempos e cruzar essa análise com a realidade arqueológica já conhecida.

Palavras-chave: Ourém, Arqueogeografia, Heranças, Geomorfologia, Transmissões.
\end{abstract}

\begin{abstract}
The study of aerial photography through photointerpretation and photointerpretation of urban morphology is not new in Archaeology, although it is increasingly used to draw conclusions within this field. In addition to identifying possible archaeological sites, aerial photography is also a resource for reading urban morphologies. In fact, it is very useful for the perception of the evolution of the layout of an urban network. When observing a landscape - urban or not - we must always pay attention to its dynamism. Thus, through the detection of Isotopic, Isoaxial and Isocline transmissions, we propose to develop a proposal for the morphological evolution of the Medieval Nucleus of Ourém over time and cross this analysis with what is already known within archaeological reality.
\end{abstract}

Keywords: Ourém, Archeogeography, Inheritances, Geomorphology, Transmissions.

Os trabalhos de arqueologia preventiva promovidos desde 2002, no topo do monte onde se conhece o castelo medieval e as vertentes, até às cotas onde figura a Colegiada, revelaram ocupações pré-históricas e proto-históricas.

A presença humana no território de Ourém fica mais pi menos clara para todos os períodos, ainda que por vezes apenas a topografia faça presente aqueles vestígios nunca encontrados.

A natureza cársica do território, a presença de rios e ribeiras e a linha de água subterrânea que alimenta a nascente que emerge no interior do Castelo, a proximidade do mar, a localização central, entre o norte e o centro peninsular, e a boa visibilidade proporcionada pela elevação, trouxeram sempre boas condições ao povoamento, nomeadamente desde o Calcolítico.
O território de Ourém abarca as bacias hidrográficas do rio Lis e do Rio Nação e, naturalmente foi sempre um excelente espaço de circulação, em direcção a qualquer um dos pontos cardiais.

Partimos deste local tão marcante na paisagem oureense e propomos uma análise morfológica da área atendendo aos mecanismos da Arqueogeografia.

Será possível reconhecer na Arqueogeografia o desenvolvimento da Arqueologia da Paisagem de tradição francesa nas últimas décadas, tendo para isso contribuído, na década de 1990, a multiplicação de escavações arqueológicas, especialmente de parcelários, no âmbito da Arqueologia Preventiva, que permitiram conhecer a transmissão das formas da paisagem no espaço e no tempo. Por conseguinte, expuseram a "crise", já perceptível, no estudo do

1. Arqueólogo, Divisão de arqueologia da Ediestreido, Lda.; adonasbotto@gmail.com.

2. Arqueóloga, Divisão de arqueologia da Ediestreido, Lda.; agape@sapo.pt 
espaço das sociedades do passado, visível no desgaste das disciplinas, como a Geografia Histórica, a Geohistória, a Geografia Agrária e a Arqueologia da Paisagem, e dos objectos, maioritariamente planimétricos, de investigação tradicional (FREITAS, 2017, p. 82).

Rober Fossier será o autor da mais antiga ocorrência do termo Arqueogeografia. Porém, a formalização da disciplina só ocorrerá a partir de 2000 com o projecto Traité d'archéogéographie. A Arqueogeografia, como disciplina, debruça-se sobre a geografia e as dinâmicas históricas dos espaços e dos meios das sociedades do passado. É uma disciplina da memória e da transmissão das formas. Com a Arqueogeografia, é possível esclarecer os contributos obtidos através dos métodos de teledetecção e dos métodos de análise das formas para o conhecimento das múltiplas heranças que se manifestam, nas formas mais recentes (DONAS-BOTTO, 2012, p. 48). "A forma é a totalidade da unidade complexa organizada que se manifesta fenomenicamente enquanto todo no tempo e no espaço" (MORIN apud COSTA, 2010, p. 43). As formas apresentam-se de diversos modos, não obedecendo a um tempo cíclico, são um testemunho daquilo que já foi. Revelam-se como fósseis do passado na paisagem rural e urbana (DONAS-BOTTO, 2012, p. 48)!

Gérard Chouquer (2007, p. 39), afirma que são três as categorias principais do discurso arqueogeográfico: o espaço geográfico, o tempo histórico e os objectos territoriais identitários.

Do ponto de vista do Espaço Geográfico a composição que a Arqueogeografia visa alcançar é a leitura do "écoumène" (ibid. 2003, pp. 13-21). Valorizando-se a dimensão geográfica do ser humano, algo que o geógrafo Augustin Berque apelidou de "géographicité" (CHOUQUER, 2007, p.55). Para este autor, a Arqueogeografia propõe-se a restaurar esta relação integrando principalmente as formas e cartas dos geógrafos. O conceito de "médiance", dá-nos a conhecer esta relação (isto é, a dimensão geográfica), sendo enriquecida pelas dinâmicas espaço-tempo. Assim, surge a ideia que entre os seres humanos e as "coisas geográficas" nascem contornos que aparentam, pelo menos aos nossos olhos, serem imóveis na cartografia e/ou na fotografia aérea (FREITAS, 2015, p. 42).

Por outras palavras, este conceito de "médiance" subentende as relações que se estabelecem entre o material e o imaterial; entre o subjectivo e o ob- jectivo; entre o passado, o presente e o futuro. Este processo dinâmico, que observamos nas fotografias aéreas, requer transformação para que haja transmissão, proporcionando ao conceito de "médiance" a dimensão espaço-tempo que lhe faltava. Demonstra, assim, a ligação entre o histórico e o geográfico, revelando o erro dos que opunham à dinâmica dos factos históricos a imobilidade das coisas dos espaços geográficos (Ibid).

Já no que respeita ao tempo histórico, a Arqueogeografia constata que o espaço não comporta apenas traços históricos associados às diferentes intervenções que os homens aí desenvolveram, mas também, e sobretudo, uma memória (ibid.: 39). Perante esta evidência arqueogeográfica devemos substituir as origens, prática comum e instaurada pela História, pelas heranças (CHOUQUER, 2007, p. 39). Os historiadores foram sempre confrontados com a dificuldade de determinar as cronologias das planimetrias e dos objectos geográficos, isto porque não reconhecem a complexa natureza das temporalidades. Acresce a esta dificuldade, os elementos de datação propostos, os quais visam permanecer na periodização e cujas referências são originárias da História. Consequentemente, estes objectos geográficos são sempre interpretados como "marcas" das instituições e das políticas, excluindo-lhes uma história diferente da dos documentos escritos (FREITAS, 2015, p. 43).

Em face destes conhecimentos, Gérard Chouquer estabelece uma orientação arqueogeográfica para o estudo das planimetrias assente num conhecimento profundo e melhorado das planificações, assim como das suas condições de realização e cronologias (CHOUQUER, 2007, p.63). É igualmente importante ter em mente que nunca conheceremos o que as planificações foram no seu momento inicial, mas sim no que elas se transformaram (FREITAS, 2015, p. 43).

$\mathrm{Na}$ última das três principais categorias do discurso arqueogeográfico entramos, explicitamente, no Naturalismo. Em Arqueogeografia, a ligação entre o Naturalismo, como base filosófica de compreensão do mundo, e a Modernidade, como tempo de emergência e consolidação desta ontologia, é imediata. A percepção desta ligação é crucial, já que dela nascem as três principais metodologias: Naturalismo, $\mathrm{Na}-$ cionalismo e Historicismo metodológico (CHOUQUER, 2007, p. 114). Podemos interpretá-las, respectivamente, como os efeitos da separação entre a 
Natureza e a Cultura; do Nacionalismo na concepção dos objectos antigos, medievais e modernos; das periodizações dos historiadores na compreensão das diversas dinâmicas (WATTEAUX, 2014).

Os objectos territoriais identitários corresponderão aos objectos geográficos, carregados de heranças, que foram recuperados, ou manipulados, pelo $\mathrm{Na}$ cionalismo na formação da sua identidade. Esta crise dos objectos, acontece, por duas razões principais: uma, os historiadores e arqueólogos construíram o passado tendo em mente o nascimento, seguido da consolidação, dos Estados-nação; outra, os investigadores procuraram nos diferentes passados as razões que permitissem justificar as suas actuais escolhas. Poderemos utilizar a Geografia Histórica como exemplo desta abordagem. Tradicionalmente, a Geografia Histórica instaura objectos periodizados e estáticos, já que pouco ou nada evoluem nos respectivos períodos. Contudo, paradoxalmente, relacionam-se explicitamente entre eles, surgindo frequentemente associados (a diocese em relação à cidade da Antiguidade, a aldeia em relação à paróquia medieval, etc). Através destas filiações pretendem-se utilizar os feitos e objectos emblemáticos de forte valor identitário e histórico (territórios, paisagens, sítios, monumentos, etc.) para justificar o que é, e como é, o actual território nacional (FREITAS, 2015, p. 44/5).

Tal como temos vindo a desenvolver, para além das fontes escritas bem como vestígios arqueológicos deveremos abordar outras fontes de estudo. Nesta vertente da investigação científica deveremos começar a considerar um maior número de documentação existente como fontes para a mesma (CHOUQUER, 2007, p. 217). Devemos então acrescentar aqui também a documentação das fotografias aéreas como fonte para este nosso exercício.

O estudo da fotografia aérea através da fotointerpretação e da fotointerpretação da morfologia urbana não é novidade na Arqueologia, ainda que cada vez mais se recorra a ela para tirar conclusões do foro arqueológico. Para além da identificação de possíveis sítios arqueológicos, a fotografia aérea é também um recurso para a leitura de morfologias urbanas. - Aliás, é bastante útil na percepção da evolução do traçado da malha urbana. A forma como a cidade cresce e se organiza está estritamente relacionada com o seu passado, deixando marcas possíveis de visualizar através das suas cartas e fotografias.

Ao observarmos uma paisagem - urbana ou não - devemos sempre ter em atenção o seu dinamismo. Não podemos adoptar uma postura coerente com um modelo palimpsesto (DONAS-BOTTO, 2012, p. 50); a paisagem, na realidade, não é composta por diversas camadas que se sobrepõem do mais recente para o mais antigo (COSTA, 2010, p. 43). Estas camadas de facto existem, mas não são opacas, e, se olharmos com atenção, é-nos possível ver a sua interligação (DONAS-BOTTO, 2012, p. 50). Conseguiremos assim, desta forma, assimilar as heranças existentes na planimetria urbana.

É nesta perspetiva que abordaremos o centro histórico de Ourém, nomeadamente o seu Castelo e envolvência urbana, socorrendo-nos dos dados de recentes escavações arqueológicas ${ }^{3}$, para tentar validar as interpretações por técnicas de observação remota. Assim, através da detecção de transmissões Isotópicas (transmissões feitas directamente sobre uma antiga estrutura, ou antiga orientação), Isoaxiais (não estando localizadas directamente sobre antigos traçados, mas que seguem as direcções anteriores) e Isoclinas (transmissões que não se encontram directamente ligadas com as formas antigas, mas cuja orientação toma como estas o seu ponto de partida) (Ibid, p. 52). Propomo-nos desenvolver uma proposta de evolução morfológica do núcleo medieval de Ourém ao longo dos tempos e cruzar essa análise com a realidade arqueológica já por nós conhecida. Este exercício, acaba por revelar a dinâmica no crescimento contra a estática da localização. Na realidade, existe um elemento estático nesta situação, a localização da vila naquele local, a fixação de gente naquele sítio específico, em contrapartida a dinâmica da sua evolução deita por terra o modelo do palimpsesto, o passado não foi totalmente apagado e

\footnotetext{
3.-Nomeadamente a intervenção arqueológica no morro do Castelo que ocorreu em 2003, na Rua Beato Simão Lopes e no Largo da Sé Colegiada. A segunda, a cerca de 150 $\mathrm{m}$ a SE da primeira, ocorreu em 2004, num terreno marginado pela rua Gonçalo Hermingues. No âmbito destes trabalhos recolheu-se um razoável conjunto de cerâmica fina cinzenta da Idade do Ferro, bem como outros variados indícios, nomeadamente do Período Medieval e Moderno. Em 2005, no âmbito de um projecto de recuperação e salvaguarda do castelo, promoveu-se a abertura de diferentes sondagens no seu interior, em redor da cisterna existente. Em 2008 procedeu-se aí a uma escavação em área pretendendo clarificar-se a estratigrafia deste sítio, ocupado desde o Calcolítico. Em 2009 efectuaram-se sondagens a norte do Castelo que nos remetem para o período Moderno. Em 1017 e 18 intervencionaram-se contextos similares.
} 
ficou vincado na morfologia adoptada pelas ruas e sua disposição.

"Cada núcleo urbano assemelha-se a um organismo vivo" (SÁ, 2001, p. 31), o crescimento da povoação a evolução cronológica do sítio adapta-se à situação. Com a desnecessidade da existência de muralha para efeitos defensivos, e sobretudo com o seu abandono definitivo após os danos do terramoto de 1755, muita da sua pedra acabou por ser reaproveitada para a reconstrução do casario da vila medieval bem como utilizada em novas construções. Muitas destas construções acabaram por assumir a mesma orientação dos antigos níveis de muralha. Desta for$\mathrm{ma}$, as novas ruas que surgiram adotaram o traçado da mesma, sendo clara esta herança na morfologia observável na fotografia aérea de Ourém. Para além desta delimitação clara de traçados de muralha conseguimos observar também uma formação rádio-concêntrica de onde irradiam traçados viários e praticamente toda a planimetria do burgo. Em termos grosseiros, podemos intuir que as redes viárias que emanam a partir destes centros são muito antigas, tão antigas como os vestígios arqueológicos mais antigos aí presentes (COSTA, 2010, p. 63).

Num primeiro ponto podemos assinalar uma área a verde que corresponderá à herança mais antiga e marcante de todo o morro. Esta área corresponderá inicialmente a uma ocupação proto-histórica e posteriormente será a "semente" de onde irá germinar o burgo medieval (Figura 1).

Confirmou-se, durante os trabalhos de 2008, a ocupação do Calcolítico (240o e 2200 a.C) escavando-se duas estruturas negativas, de tipo fossa, preenchidas por restos faunísticos artefactos dessa época (PEREIRA, 2011, 154)

As técnicas e motivos decorativos são diversificados, sendo que se denota um cruzamento de influências do Calcolítico Beirão (o caco com penteados) e Estremenho (o caco decorado com folha de acácia), incluídas no Calcolítico Pleno (CARVALHO, 2010/2011). No ano de 2003, junto à Colegiada de Ourém, sob a muralha e no lado N, verificou-se um nível do Bronze Final e I Idade do Ferro (até cerca de 450 a. C.), nomeadamente as chamadas cerâmicas cinzentas (tratadas por meio de alisamento ou polimento) e outras de pasta clara, pintadas a cores vermelhas e alaranjadas. Mesmo que a ocupação do local tenha sofrido alguma interrupção, no final do Calcolitico, o fato é que também na escavação de 2008 (no interior do castelo) se detectaram algumas cerâmicas cinzentas. A não detecção de material de períodos posteriores à Idade do Ferro sob a muralha, recuando até ao século VII a.C., faz-nos colocar a hipótese de que o solo poderia ter sido terraplanado para a implantação da muralha. Até porque as cerâmicas da Idade do Ferro que apareceram quer nas sondagens de 2004, junto à rua Gonçalo Hermingues, na encosta oriental abaixo do cemitério (Pereira et all, 2017, p. 27) e noutros pontos do morro conduzem-nos a crer numa profunda alteração da morfologia do monte e sequente destruição de anteriores níveis e ocupação. A terraplanagem que ocorreu no interior do Castelo, permanecendo apenas os níveis mais antigos, nomeadamente do lado oeste (PEREIRA, 2011, 156). Uma operação de terraplanagem pode, por exemplo e também, justificar o desconhecimento de vestígios de ocupação muçulmana. Quando o investigador Doutor Saúl António Gomes refere a expressão "castellus de nouo" como indicativo que se construiu um castelo de raiz, cremos que não invalida a existência de uma torre de cisterna e antigas estruturas inerentes ao castro. De facto, aquela a construção de um castelo de raiz pode vir a ser reforçada com a presença do muro sob a parede leste do actual recinto triangular e sobre os níveis Pré-históricos. No entanto não se percebe ainda que muro será aquele, bem como não se coloca de lado que outros níveis tenham sido decapados à época da construção do edificado, podendo a estrutura ser medieval. Por outro lado, algumas das disposições detectadas em 2005 e o facto de a torre sul da edificação actual apresentar um aparelho em blocos de grandes dimensões, silhares com marcas de fórceps, característica típica dos séculos VIII E IX12, levam-nos a acredita na possível existência de uma dita primeira edificação - a torre da cisterna (?). (PEREIRA, 2011, 159).

Após um período de fortalecimento da zona fronteiriça, assiste-se no século XII, a um retorno à estratégia de conquista. $\mathrm{O}$ espaço, em que se insere o concelho de Ourém, não era desconhecido quer por mouros quer por cristãos, mas com certeza foi durante algum tempo uma terra que não pertenceria a nenhum dos quadrantes político militares.

As invasões de Almorávidas e Almóadas, vindas dos confins de Marrocos, pesaram duramente na maneira de viver dos cristãos, a quem não respeitavam nem a fé nem os usos. Assolados pela guerra, muitos lugares devem ter vivido, pelo espaço de algumas gerações, na insegurança das pessoas e dos 
bens: arruinadas as povoações, foragida a escassa população rural, constituíram-se alguns espaços ermos, sem cultura e sem dono. Nesta "terra de ninguém”, sem se embaraçarem com divisões de propriedades ou contestações de posse, os primeiros reis fizeram enormes doações de território às ordens militares, bens aos mosteiros e latifúndios a grandes senhores e na maioria das vezes os quadros da administração e os limites das propriedades precediam a ocupação efectiva do solo ou, pelo menos, a organização da vida rural.

Conquista por D. Afonso Henriques por volta de 1136, Abdegas não terá sido um território com ermamento total durante o período da pré-reconquista, mas também não haveria aí, até à segunda metade de XII, povoações dignas de serem referidas pelos documentos da época. À época a sua ocupação integra-se numa política de ocupação de espaço, levada a cabo por D. Afonso Henriques que, em 1135, tinha já ordenado a construção do castelo de Leiria.

É após a Reconquista do local e a construção da igreja de S.ta Maria de Ourém que D. Afonso Henriques doa ao Mosteiro de S.ta Cruz, os reguengos e a vila de Ourém são entregues a sua filha D. Teresa, em 1158, fazendo assim desta vila um investimento régio, deixando ali um delegado da sua autoridade, demonstrando a preocupação para com as ameaças vindas de sul. Desde o início da monarquia portuguesa que o castelo de Ourém é caracterizado pela presença de iniciativa régia e pela participação dos habitantes na sua defesa e manutenção, como se conclui de um diploma régio de 1178 .

É provável que já existisse um castelo em Ourém, apenas refúgio, sem carácter habitacional permanente, com dispositivos para armazenar água e alimentos onde se refugiavam as gentes dos vales de Aurem. Em torno desta área. E com o normal crescimento do burgo ter-se-á alargado a muralha dando lugar a uma cerca vilã para albergar toda a população dentro da proteção da estrutura militar. Neste momento, a área delimitada a verde terá assumido uma posição de cidadela continuando a marcar fortemente a morfologia da área (Figura 2).

Este alargamento terá certamente sofrido intervenção nos reinados de D. Fernando ou muito mais provavelmente no reinado de D. João I. Aquando da doação do condado de Ourém a D. Nuno Álvares Pereira este empreendeu algumas intervenções na área do castelo e acessos ao burgo. Em 1384, D. João I concede a Vila e o território, bem como o tí- tulo de Conde de Ourém, ao Condestável do Reino, D. Nuno Álvares Pereira (3.. Conde de Ourém). Nessa altura Nuno Álvares Pereira manda edificar a Fonte dos Cavalos. E, já no século XV, é com o neto do dito Condestável, D. Afonso Conde de Ourém e Marquês de Valença, que o território condal conheceu um período bastante dinâmico. É nessa altura que as muralhas do primitivo castelo são rasgadas para edificação do conhecido Paço do Conde, sito a sul do castelo.

Deste período temos um elemento morfológico muito marcante estando assinalado a azul na Figu-ra 2. Esta transmissão acaba por se revelar como uma transmissão Isotópicas nas áreas das ruas de São João e São José bem como na rua D. Afonso Quarto Conde de Ourém. Esta transmissão é feita directamente sobre o que acreditamos ser o alinhamento da antiga estrutura de uma primeira cerca vilã, ou pelo menos a sua antiga orientação). $\mathrm{O}$ casario que se desenvolve em torno destes eixos e na parte interior dos mesmos acabam por se revelar transmissões Isoaxiais, isto é, não estando localizadas directamente sobre antigos traçados, mas que seguem as direcções anteriores formando assim parcelários e elementos morfogenéticos. A Rua da Saudade e Calçada de Gonçalo Hermingues acabam por também assumir uma morfologia testemunho de transmissão Isoaxial (Figura 3 e 4).

Na vertente mais a este desta calçada podemos testemunhar uma transmissão Isoclina, ou seja, as transmissões não se encontram directamente ligadas com as formas antigas, mas a sua orientação toma estas como o seu ponto de partida. É neste ponto que observamos o elemento morfogenético mais marcante. Queremos com isto dizer que o parcelário antigo transmitiu a sua orientação em parte ao actual apesar das alterações que a área sofreu ao longo dos tempos bom como da sua ocupação funcional. Esta área está assinalada na Figura 5 com um polígono laranja.

Por fim poderemos observar os últimos momentos responsáveis pela morfologia urbana do Núcleo Medieval de Ourém. Na figura 5 podemos observar assinalado a vermelho o alargamento da cerca vilã com as intervenções de D. Afonso IV Conde de Ourém. A par desta observação podemos constatar os mortórios ou espaços vazios sem casario certamente consequência do terramoto de 1755 bem como das incursões militares aquando das invasões francesas. $\mathrm{O}$ terreno intervencionado, em 2009, situa-se a N 
do Castelo e toma a forma prismática e em arco, no sentido norte-sul; fica situado entre a Rua da Saudade que, vindo da porta de Santarém, leva ao cemitério (situado a sudeste), e a rua de S. João, que segue da porta de Santarém para o centro do aglomerado urbano (...). O contexto arqueológico apresentou-se similar àquele do ano de 2004, grande número de fragmentos cerâmicos, designadamente faiança portuguesa - XVII a XIX. (PEREIRA, 2011, 154)

Todas estas reformas deixaram uma marca bem patente na morfologia do burgo, se por um lado a Sé Colegiada acaba por ganhar uma posição de destaque na plataforma limítrofe norte da vila murada, o eixo concêntrico da rede viária urbana não se perde, bem como a influencia e herança primordial da área do castelo na formação de uma planimetria concêntrica e de um parcelário que vai seguindo tanto as novas como as formas mais antigas. O próprio alargamento da cerca vila acaba por se revelar uma transmissão Isoaxial assumindo agora o casario o lugar da transmissão isotópica das partes da muralha já desaparecida (Figura 6 a 8).

Tal como foi possível observar nas duas figuras anteriores o castelo mantém-se ainda hoje como ponto fulcral tanto nos parcelários urbanos como nos sentidos de fluxo da rede viária do burgo. Desta forma não deveremos assumir o castelo em si apenas como uma herança medieval, mas sim como um marco de toda a ocupação do morro, sendo esta estrutura e este ponto uma manifestação no terreno do ecohumano, de todas as formas como o ser humano moldou este morro, mas como aquele ponto manteve inalterada a sua centralidade e influencia na definição morfológica do povoado.

Concluindo, foi possível atestar as ocupações apresentadas a partir do exercício de análise das imagens de satélite da área do castelo de Ourém. Este exercício de Arqueogeografia é ainda muito preliminar, mas foi já suficiente para retirar algumas conclusões como a centralidade do castelo e da área assinalada a verde na Figura 1, a existência de pelo menos três parcelários urbanos que vão acompanhando o desenvolvimento do burgo e vão sendo reflexo da evolução do mesmo. As cercas medievais e sucessivas intervenções na área - sobretudo com a construção do paço condal - vão sendo reflexo de transmissões Isotópicas e Isoaxiais chegando a existir áreas onde os diferentes traçados se sobrepõem tal como poderemos ver nos dois esquemas finais deste artigo representados nas figuras 9 e 10. Estas cercas chegam- -nos hoje até nós não só pelos elementos que ainda hoje são visíveis dos mesmos mas também pela observação da morfologia das ruas e casario como desenvolvemos nas linhas anteriores!

Estas diferentes transmissões e parcelários correspondentes aos diferentes períodos de desenvolvimento marcados na paisagem acabam por revelar três fases evolutivas que ficaram marcadamente presentes na morfologia urbana da área (Figura 9 e 10).

\section{BIBLIOGRAFIA}

FREITAS, Bruno Bairrão de (2015) - Paisagens do Baixo Mondego: Por um debate acerca de Ega, Arrifana e PicotaDissertação, Dissertação de mestrado apresentada à Faculdade de Letras da Universidade de Coimbra, Coimbra.

FREITAS, Bruno Bairrão de (2017) - "Anatomia" de um Mito Medieval: a aldeia e a forma rádio-concêntrica. Al-Madan Online [Em linha]. II Série. N.ㅇ 21. Tomo 2 pp. 81-91.

CARVALHO, A. Faustino; NUNES, Ana; GONÇALVES, Ana; PEREIRA, Jaqueline (2010/2011) - A ocupação calcolítica do Castelo de Ourém: contextos, cultura material, zooarqueologia, cronologia absoluta e integração regional. Estudos Arqueológicos de Oeiras, 18, Oeiras, Câmara Municipal, pp. 407-418.

CHOUQUER, Gérard (2007) - Quels scénarios pour l'histoire du paysage? - Orientations de recherche pour l'archéogeographie - Centro de Estudos Arqueológicos das Universidades deCoimbra e Porto, Coimbra.

COSTA, Miguel Cipriano (2010) - Redes viárias de Alenquer e suas dinâmicas. Um estudo de arqueogeografia - Tese de Mestrado em Arqueologia e Território, Faculdade de Letras da Universidade de Coimbra, Coimbra.

DONAS-BOTTO, André (2012) - São João da Pesqueira: Subsídios para o estudo do território medieval - Dissertação de mestrado apresentada à faculdade de Letras da Universidade de Coimbra, Coimbra.

PEREIRA, Jaqueline \& GONÇALVES, Alexandre (2006) Carta Arqueológica do Concelho de Ourém, Ed. Câmara Municipal de Ourém, Ourem.

PEREIRA, Jaqueline e FERREIRA, Sofia (2011) - OURÉM: De povoado a Vila Velha, I Congresso de História e Património da Alta Estremadura, pp. 149-165.

SÁ, Alberto (2001) - Sinais da Guimarães Urbana em 1498 Dissertação de Mestrado em História e Cultura Medievais, Instituto de Ciencias Sociais, Universidade do Minho, Braga.

WATTEAUX, Magali (2014) - La terre en héritage. Espaces Temps.net. 


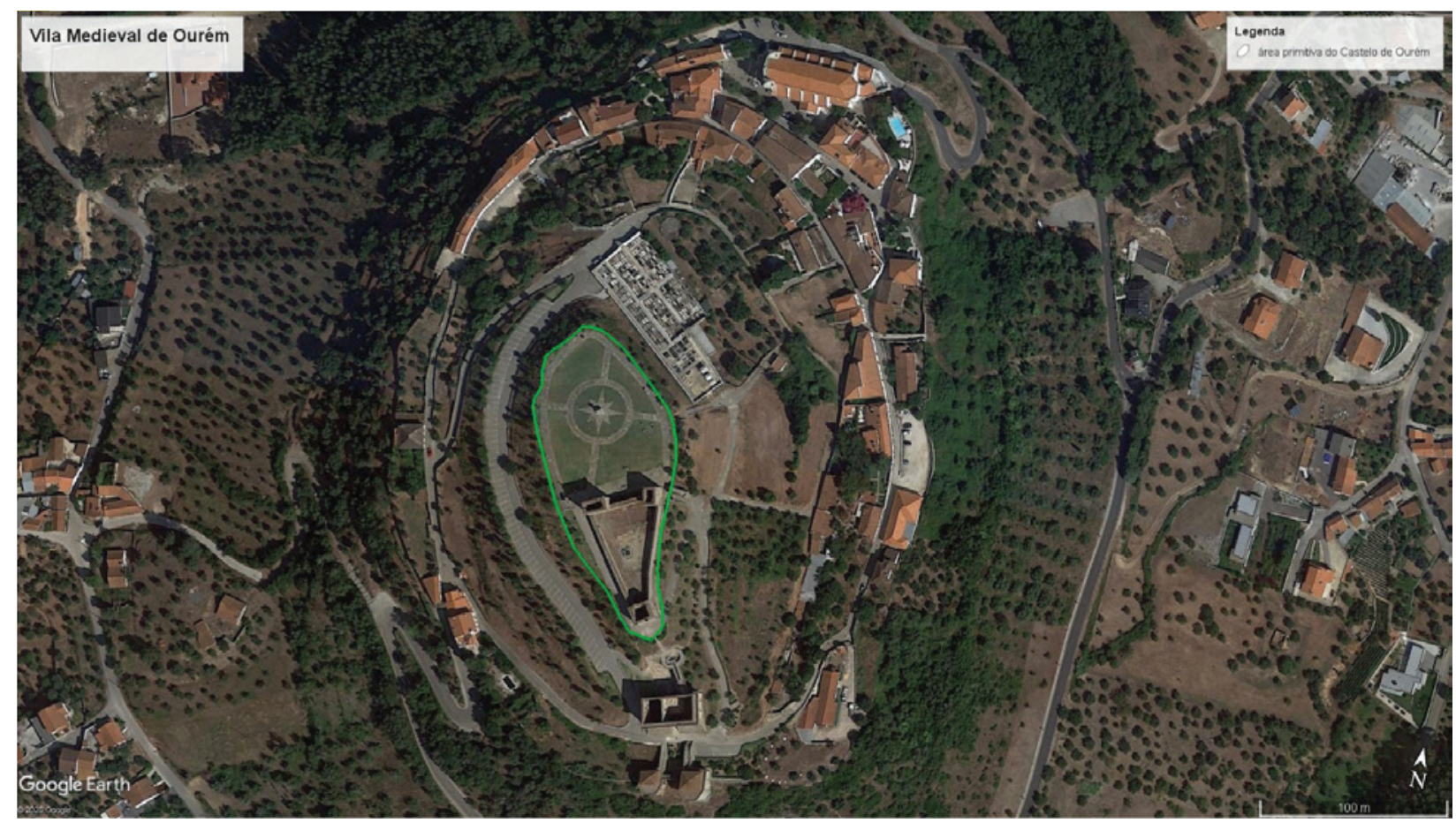

Figura 1 - Vista aérea do núcleo medieval de Ourém.-A verde está demarcada a área correspondente a área primitiva de ocupação que acabou por moldar todas a morfologia. Fonte: Google Earth.

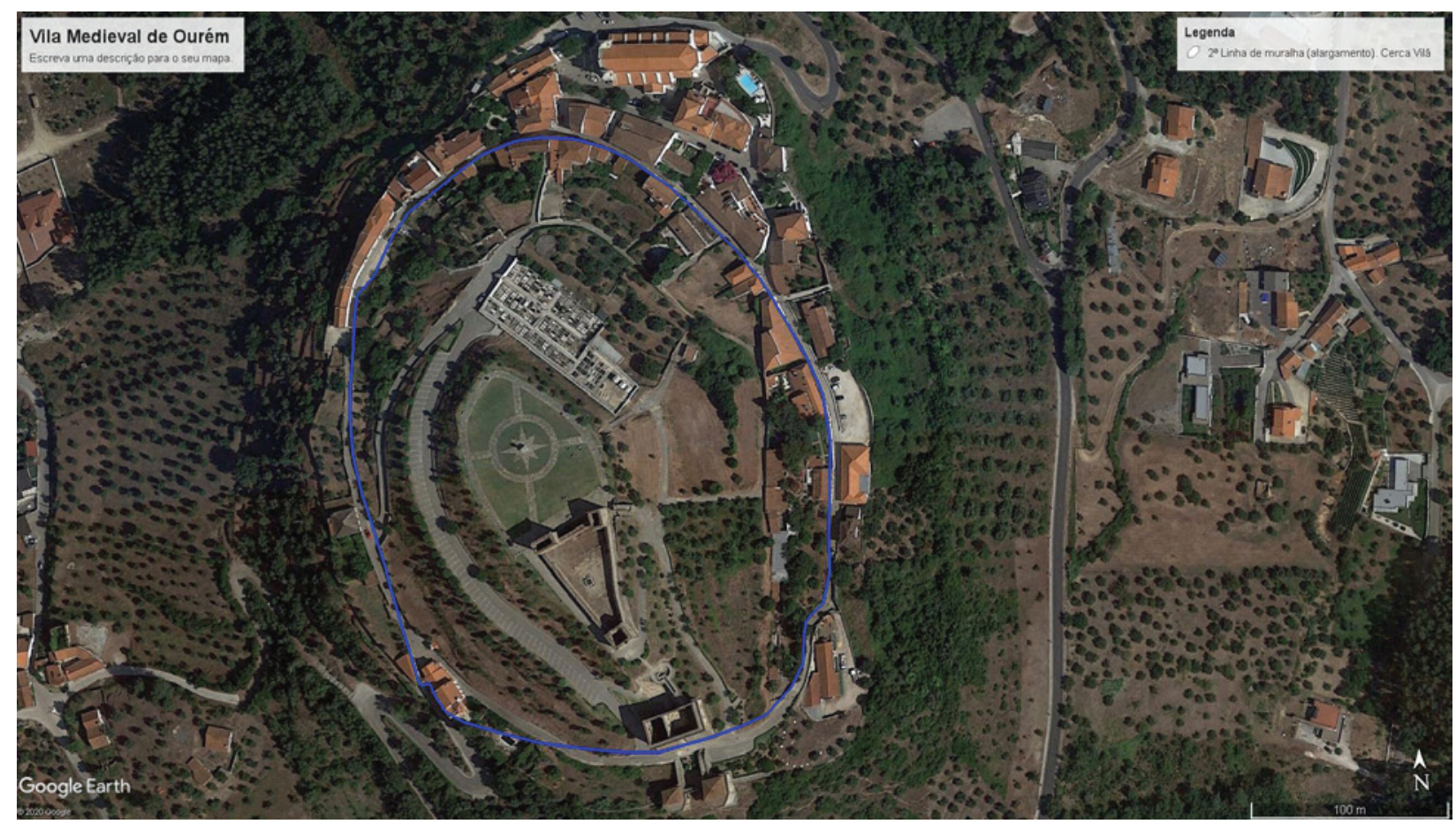

Figura 2 - Vista aérea do núcleo medieval de Ourém. -A azul está demarcada a área correspondente à cerca vilã e primeiro alargamento do burgo. Fonte: Google Earth. 


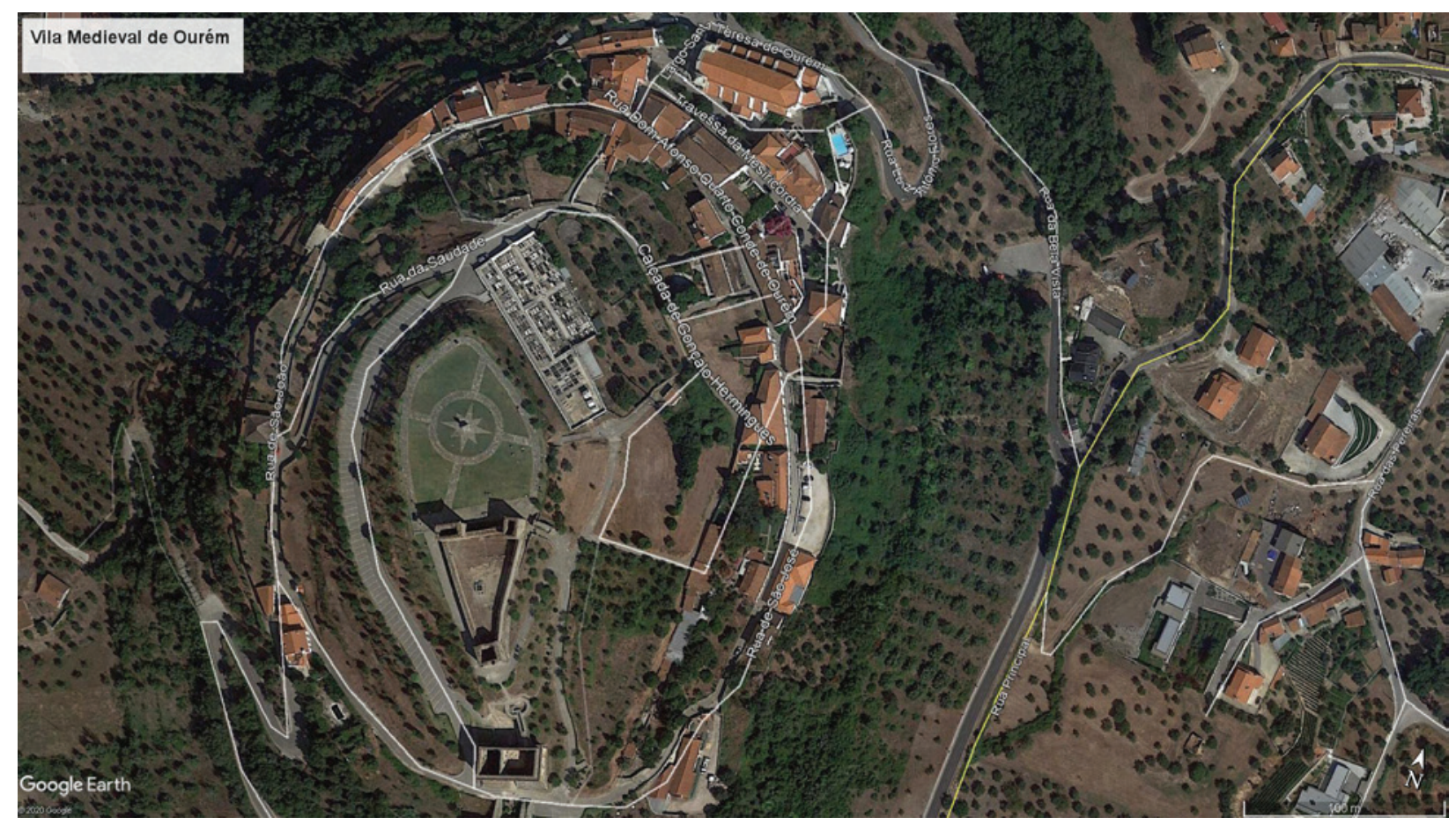

Figura 3 - Vista aérea do núcleo medieval de Ourém com os principais arruamentos assinalados. Fonte: Google Earth.

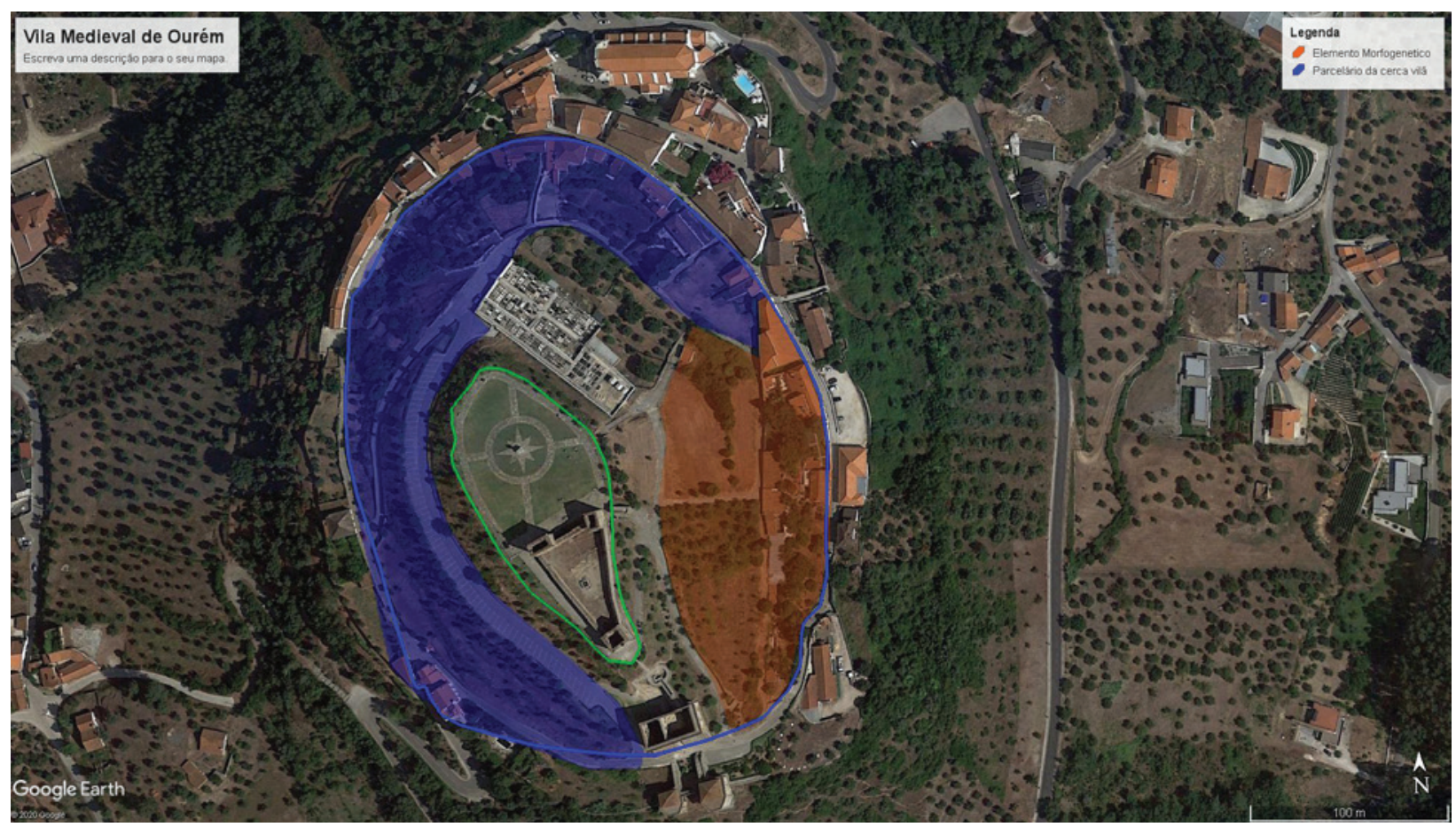

Figura 4 - Vista aérea do núcleo medieval de Ourém. Principais parcelários e transmissões isotópicas e isoclinas. Fonte: Google Earth. 


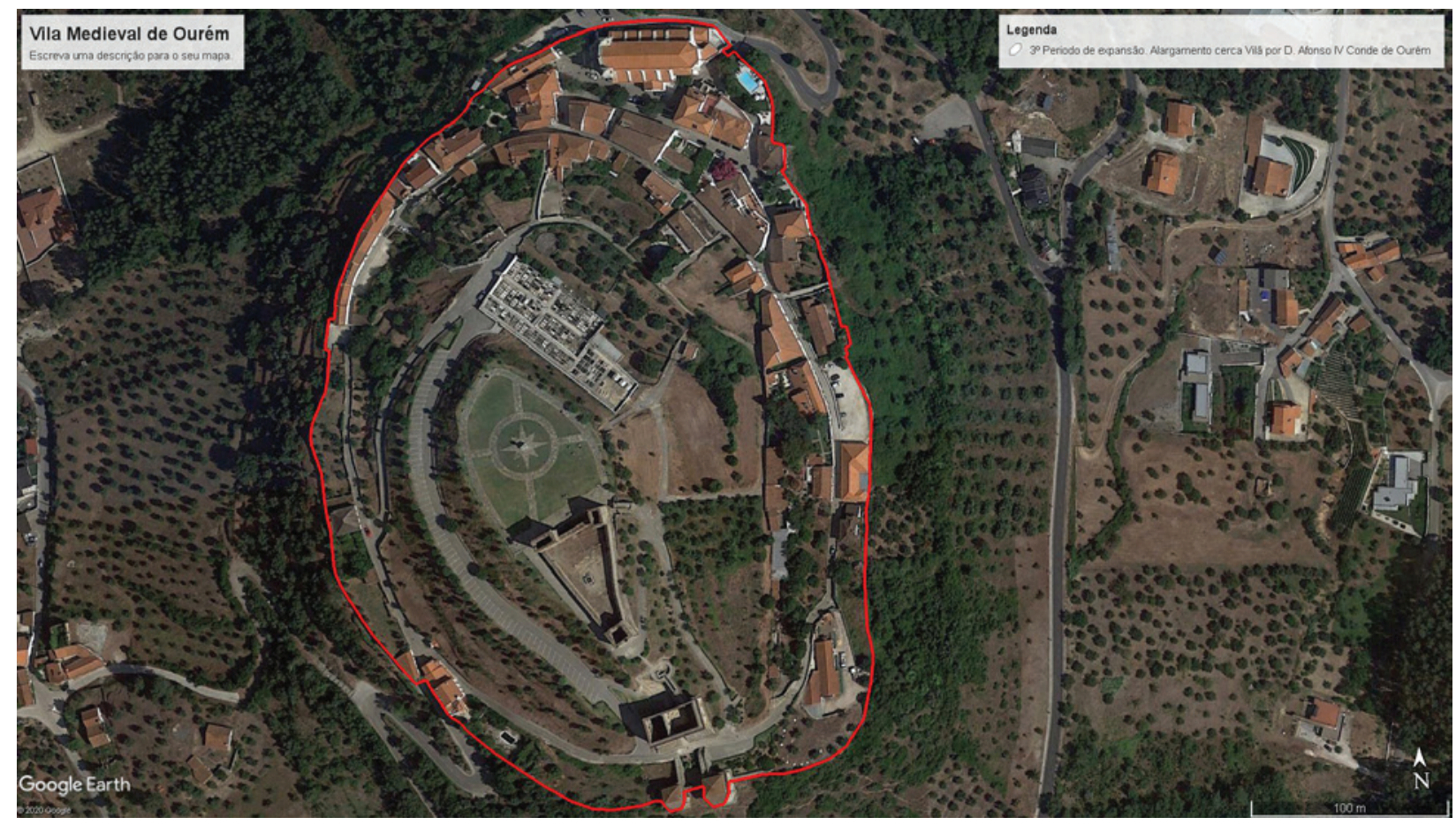

Figura 5-Vista aérea do núcleo medieval de Ourém. -A vermelho está assinalada a última linha de muralha correspondente à cerca vilã alargada. Fonte: Google Earth.

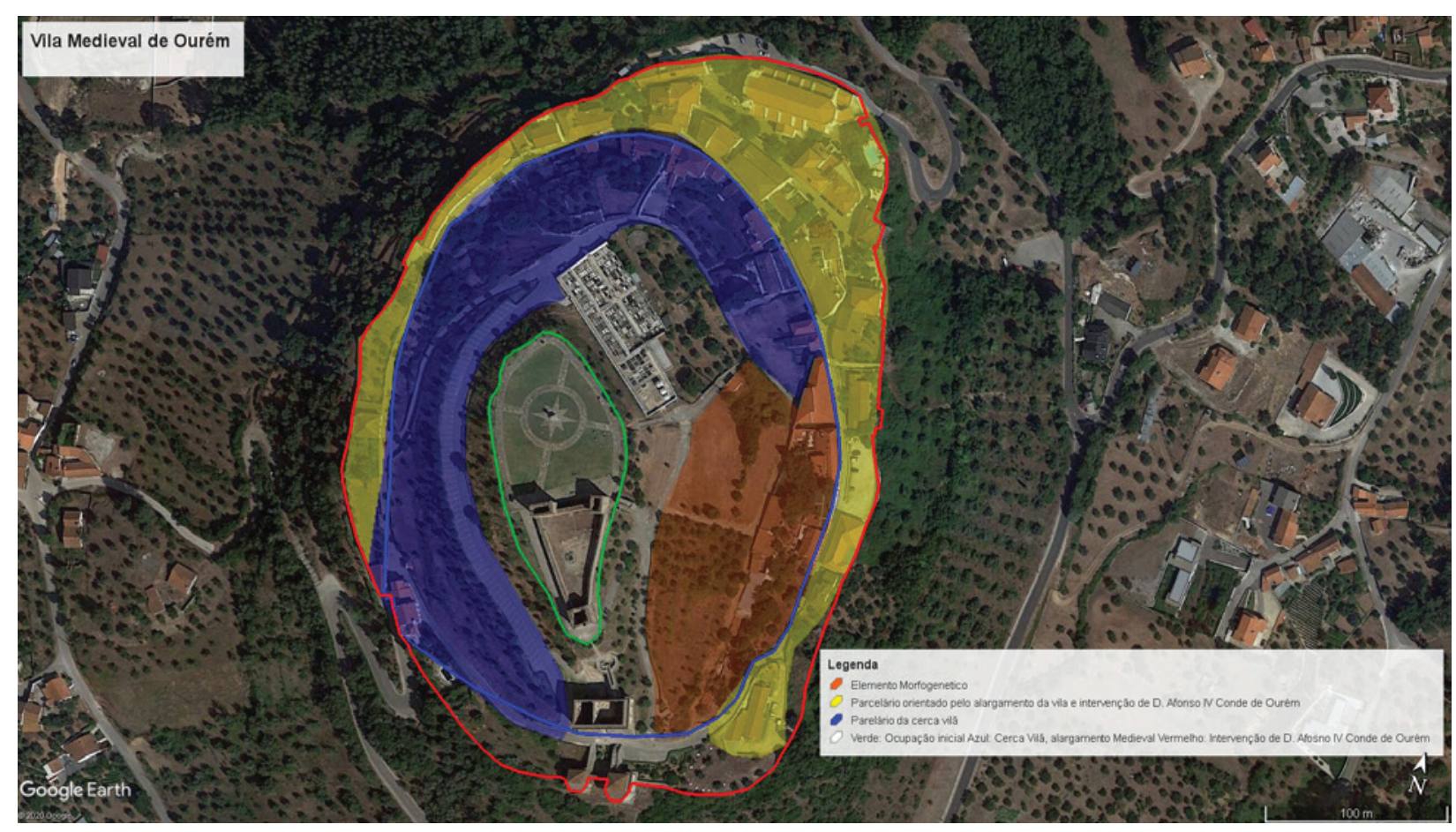

Figura 6 - Vista aérea do núcleo medieval de Ourém. Com os três parcelários assinalados. Fonte: Google Earth. 


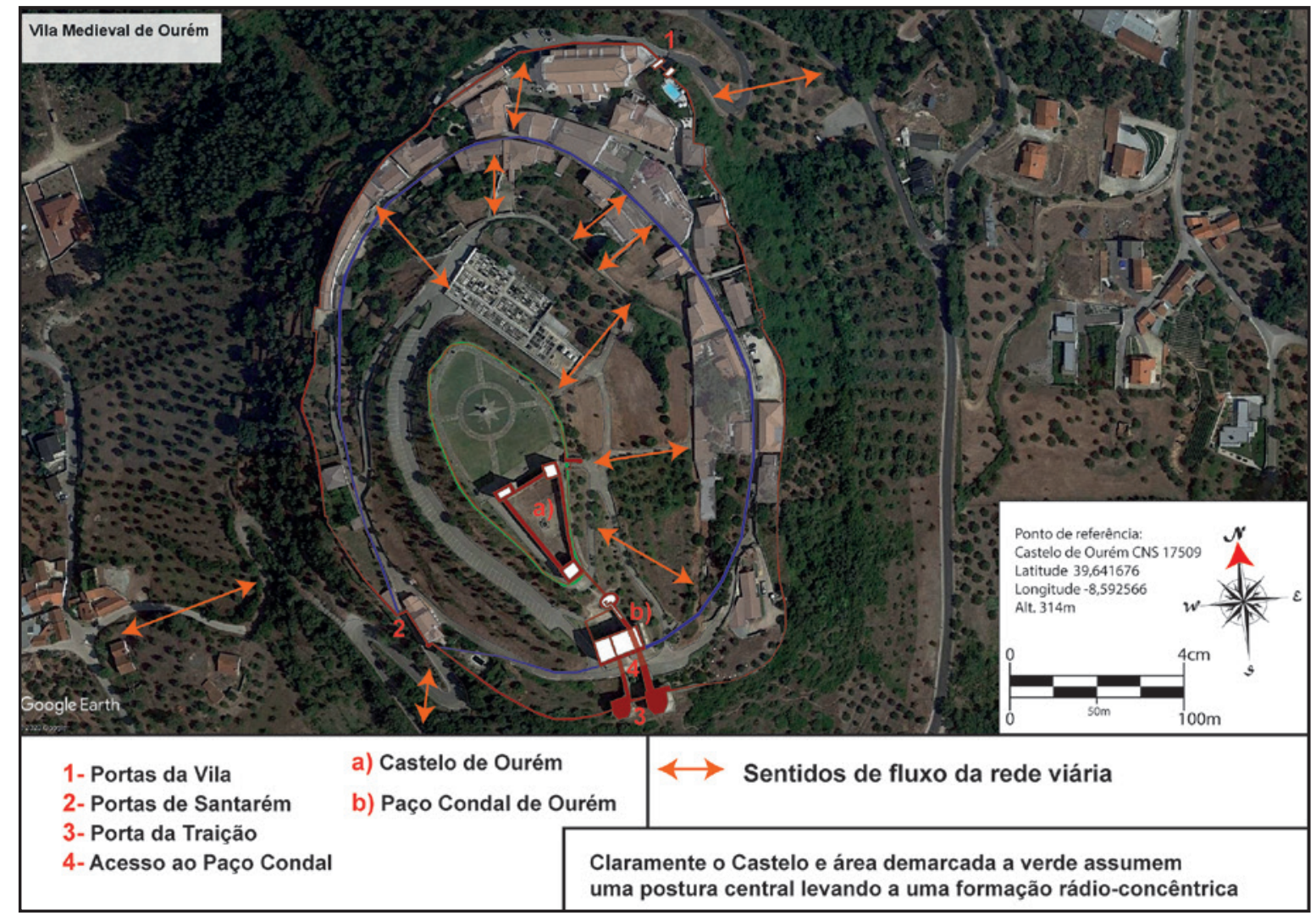

Figura 7 - Vista aérea do núcleo medieval de Ourém. Indicadores de sentidos de fluxo e formação rádio-concêntrica. Fonte: Google Earth.

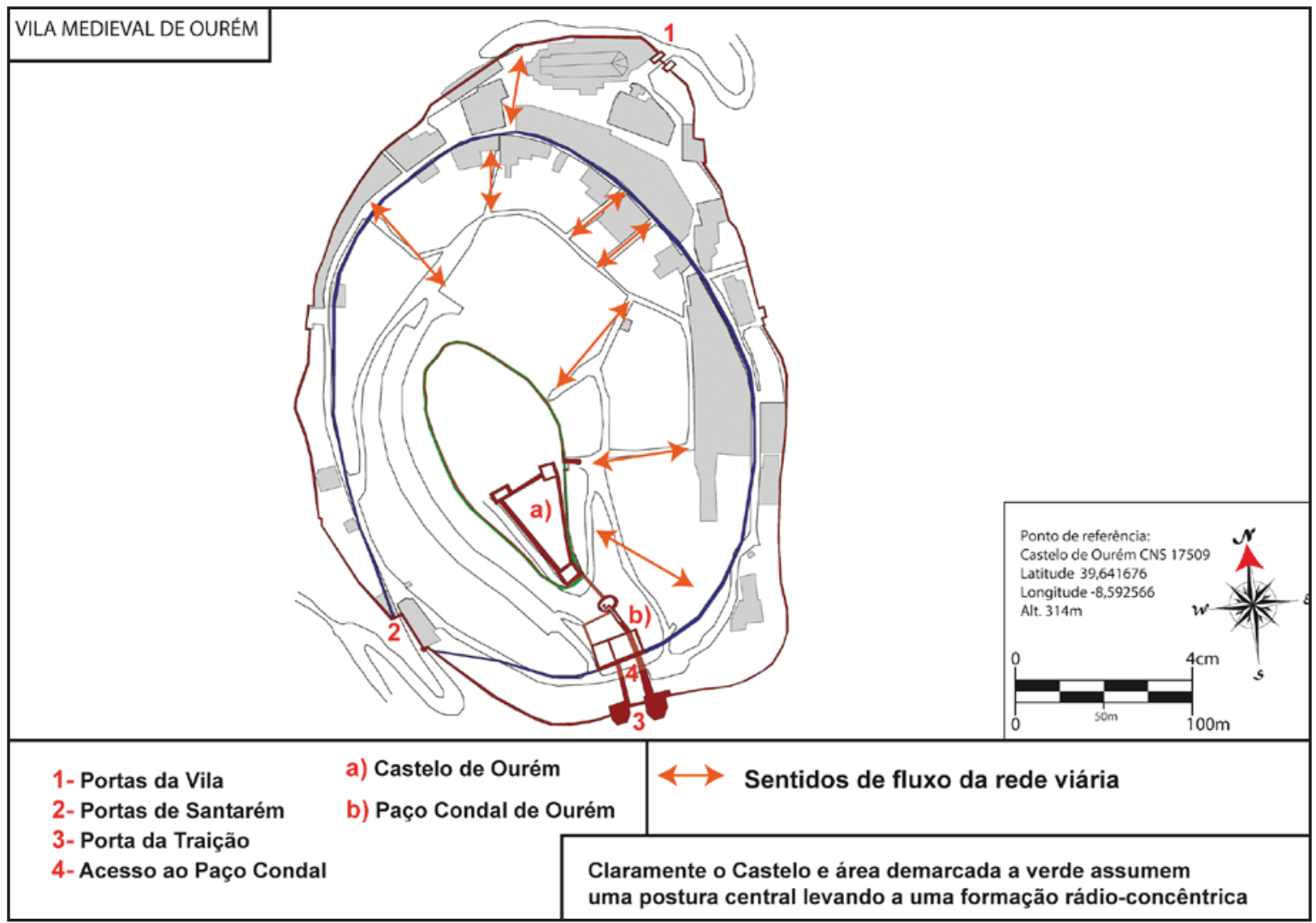

Figura 8 - Indicadores de sentidos de fluxo e formação rádio-concêntrica. 


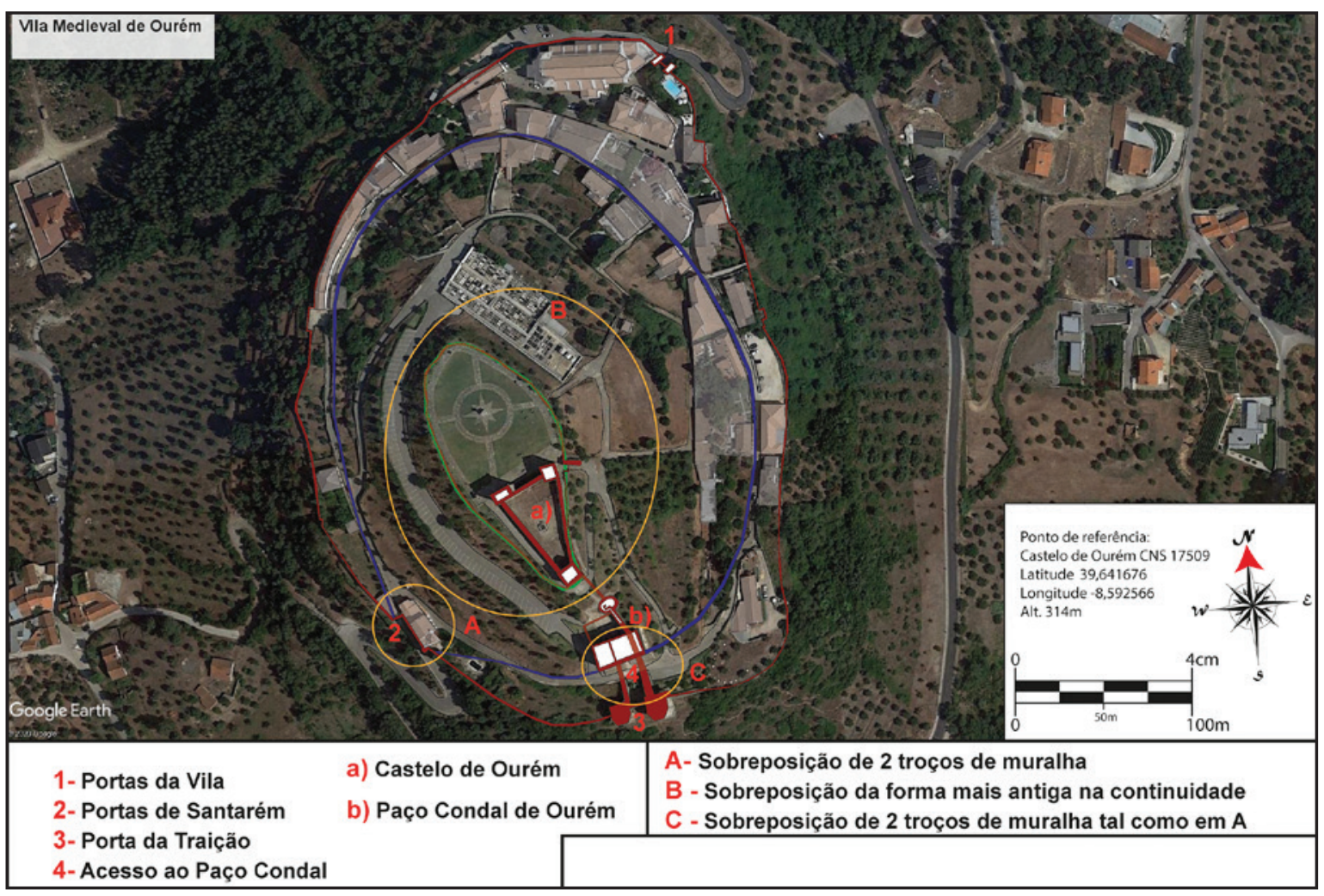

Figura 9 - Vista aérea do núcleo medieval de Ourém com as principais formas e transmissões assinaladas. Fonte: Google Earth.

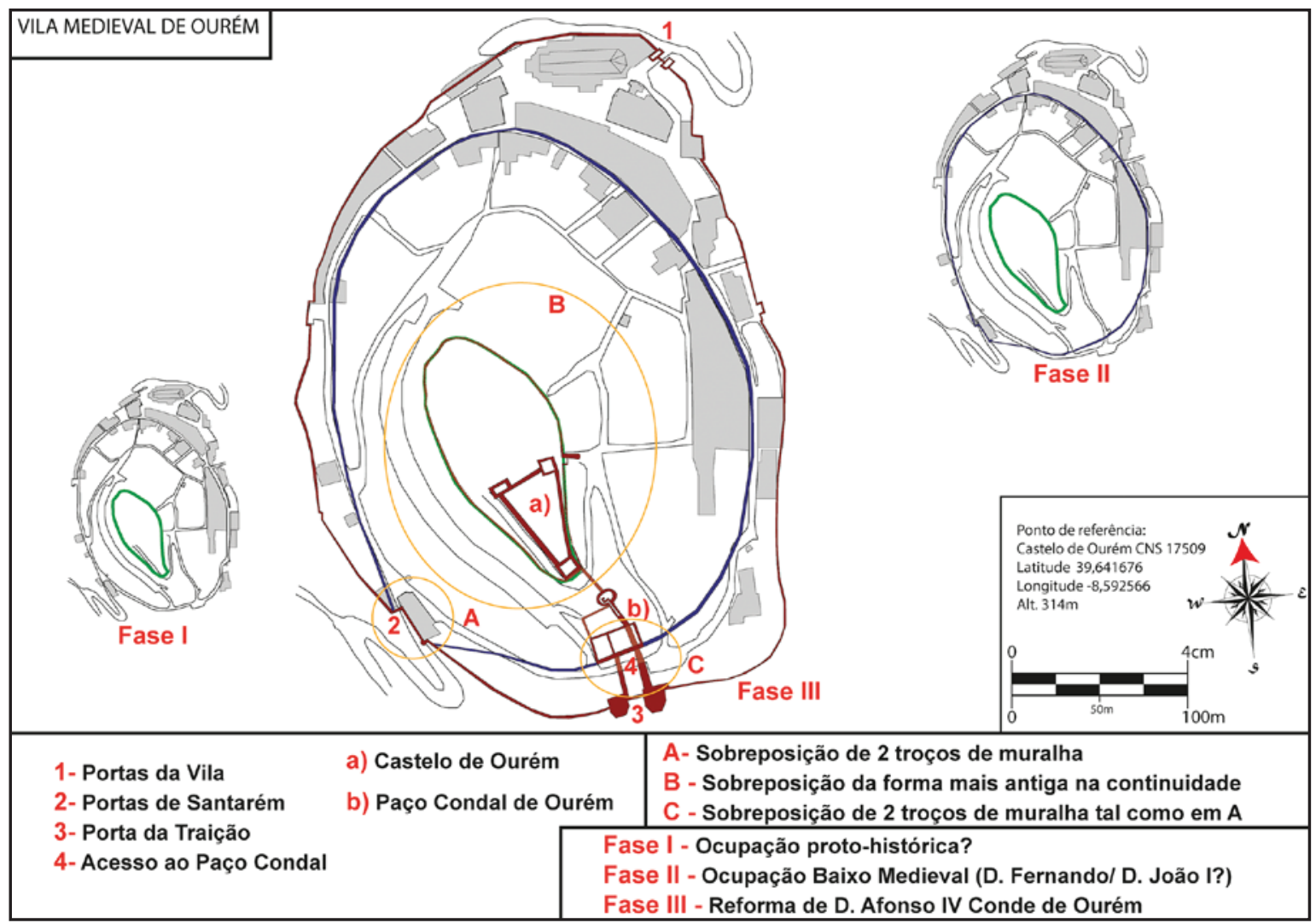

Figura 10 - Esquema interpretativo da evolução do núcleo medieval de Ourém com as principais formas e transmissões assinaladas. Fonte: Google Earth. 


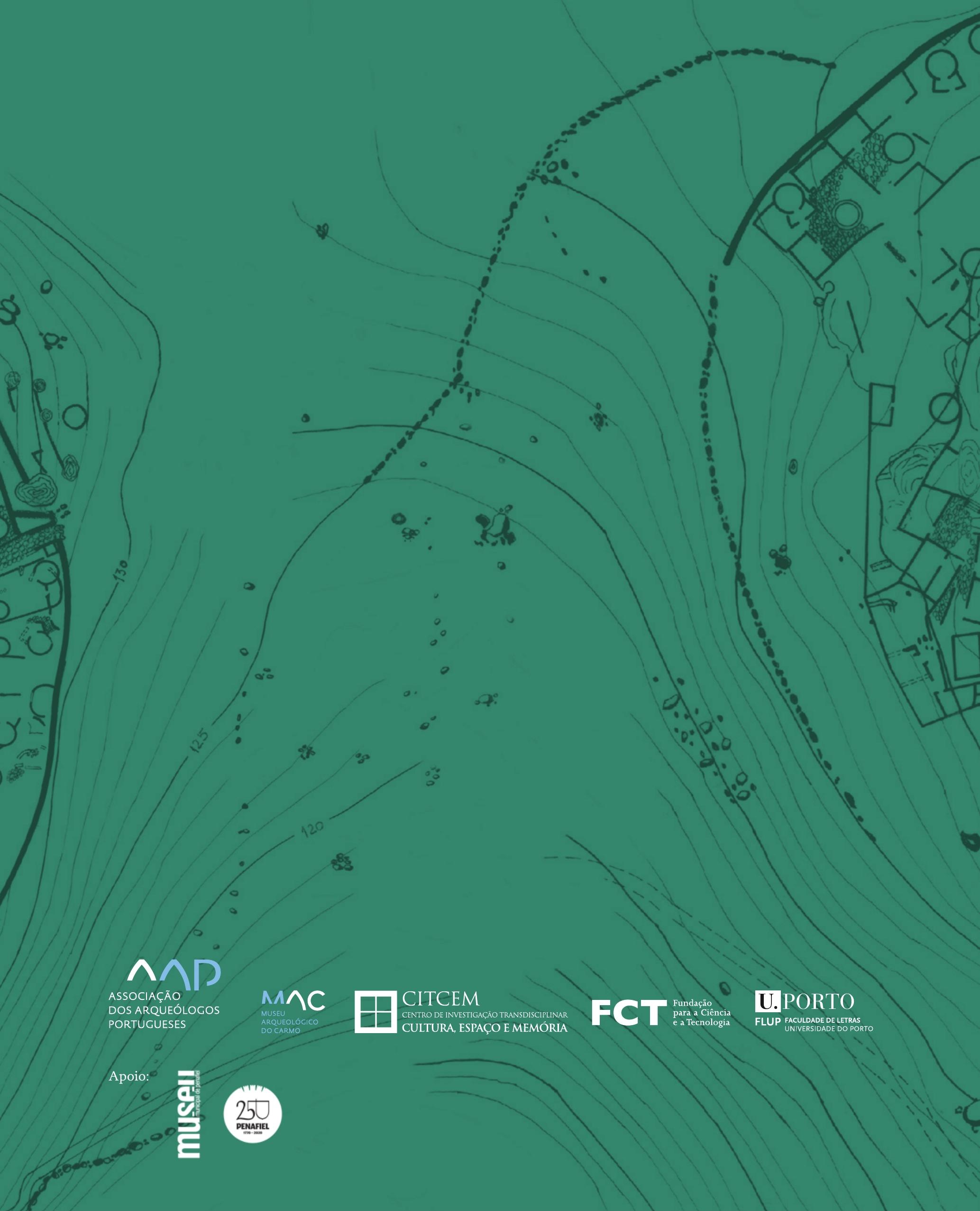

